Research Paper

\title{
Characterization of antibiotic resistance in Salmonella enterica isolates determined from ready-to-eat (RTE) salad vegetables
}

\author{
Birce Mercanoglu Taban ${ }^{1}$, Sait Aykut Aytac ${ }^{2}$, Nefise Akkoc ${ }^{3}$, Mustafa Akcelik ${ }^{3}$ \\ ${ }^{1}$ Vocational School of Health Services, Gazi University, Golbasi, Ankara, Turkey. \\ ${ }^{2}$ Food Engineering Department, Faculty of Engineering, Hacettepe University, Beytepe, Ankara, Turkey. \\ ${ }^{3}$ Biology Department, Faculty of Science, Ankara University, Tandogan, Ankara, Turkey.
}

Submitted: June 10, 2011; Approved: June 5, 2012.

\begin{abstract}
In the last decade, ready-to-eat (RTE) salad vegetables are gaining increasing importance in human diet. However, since they are consumed fresh, inadequate washing during processing can bring on some foodborne illnesses, like salmonellosis, since these food items have natural contamination from soil and water. During 2009-2010, a total of 81 samples were purchased arbitrarily from local markets in Ankara, and were examined for Salmonella contamination. Salmonella screening was performed by using anti-Salmonella magnetic beads system and polymerase chain reaction (PCR) identification of the suspected colonies. Then, the antibiotic resistance profiles of four Salmonella strains identified (strains RTE-1, RTE-2, RTE-3, and RTE-4) were also investigated, since the mechanism by which Salmonella spp. have accumulated antibiotic resistance genes is of interest. All strains showed resistance against sulfonamides (MIC $>128 \mathrm{mg} / \mathrm{L}$ ). Further results suggested that associated sulfonamide resistance genes were encoded by the $55.0 \mathrm{~kb}$ plasmid of strain RTE- 1 that involves no integrons. As a result of using two primers (P1254 and P1283) in randomly amplified polymorphic DNA-PCR (RAPD-PCR) analysis, two common amplicons (364 bp and 1065 bp) were determined. The findings of this study provide support to the adoption of guidelines for the prudent use of antibiotics in order to reduce the number of pathogens present on vegetable and fruit farms. Besides, since it is shown that these bacteria started to gain resistance to antibiotics, it is necessary to further investigate the prevalence of them in foods.
\end{abstract}

Key words: contamination, plasmid-mediated sulfonamide resistance, ready-to-eat salad vegetables, food safety, Salmonella.

\section{Introduction}

Ready-to-eat (RTE) food is defined by EC Regulation No. 2073/2005 as the food intended by the producer or the manufacturer for direct human consumption without the need of cooking or other processing effective to eliminate or reduce to an acceptable level microorganisms of concern (European Commission Regulation-EC No 2073, 2005). Among these RTE food types, RTE salad vegetables have been gaining importance due to arise of presence and prevalence of pathogen bacteria (Beuchat 1996; Wells and Butterfield 1997; de Curtis et al., 2002; Fröder et al., 2007; Little et al., 2007).
Since RTE salad vegetables are generally considered healthy to eat because of their vitamin, mineral, and antioxidant contents, their consumption in modern life has increased both in quantity and variety in recent years due to this increasing demand of consumers (de Giusti et al., 2010). With this increase in consumption of RTE salad vegetables, it also comes with the increased potential for exposure to foodborne pathogens through this food chain. These foods may receive some degree of minimal technological processing before commercial distribution. However, since they are consumed fresh, inadequate washing during processing can bring on some foodborne illnesses like salmonellosis, since these food items have natural contamination 
from soil and water (Abadias et al., 2008). According to the foodborne diseases outbreaks report, which was released by the Public Health Laboratory Service (PHLS) Communicable Disease Surveillance Centre (CDSC) during 19922000, among 1518 foodborne general outbreaks of infectious intestinal disease, $83(5.5 \%)$ were associated with the consumption of salad vegetables or fruit, and Salmonella spp. were the most frequently reported (41.0\%) pathogens (Long et al., 2002; Ward et al., 2002).

EC Regulation No. 2073/2005 also contains food safety criteria for Salmonella in precut vegetables, herbs and fruits placed on the market. Salmonella spp. should be absent in all RTE salad vegetables, fresh herbs and fruits (Little and Gillespie, 2008).

A study of retail bagged RTE salad vegetables carried out during 2001 uncovered an outbreak of $S$. Newport PT33 (Sagoo et al., 2003). Five of 3853 bagged RTE salad vegetable samples in 2001 were contaminated with $S$. Newport PT33 (one sample), $S$. Umbilo (three samples) and $S$. Durban (one sample), which indicates an important health risk. Nineteen cases of $S$. Newport PT33 infection were subsequently identified throughout England and Wales (Ward et al., 2002).

The emergence of antibiotic resistant foodborne pathogens is another public health concern. Several organizations, including the World Health Organization (WHO) and Centers for Disease and Prevention (CDC), have all stressed the need to control the spread of this resistance (Angulo et al., 2000). The levels of resistance are varied and influenced by antimicrobial use in vegetables and fruits, as well as the geographical differences.

The aims of this study were to evaluate the presence of Salmonella in RTE salad vegetables, and also to characterize the antibiotic resistance of $S$. enterica isolates.

\section{Materials and Methods}

Eighty one RTE salad vegetable samples were arbitrarily purchased from several markets and retail premises at the point of all over the city Ankara, Turkey, during 2009-2010. RTE salad vegetable samples represent different mixtures of greens and other vegetables found at the markets and retail premises at the moment of sampling hence the number of samples was also obtained arbitrarily. Salmonella screening in each RTE salad vegetable sample was performed by using anti-Salmonella magnetic beads (Dynal ${ }^{\circledR}$, Norway) system as an alternative to the selective enrichment step in the conventional determination method (ISO 6579:2002), and the suspected colonies were further identified by the optimized polymerase chain reaction (PCR) method (Mercanoglu Taban et al., 2009). Only four isolates were found as Salmonella by PCR.

Plasmids of these 4 Salmonella strains were isolated using the method of Kado and Liu (1981) with modifications of Helmuth et al. (1985) and Guerra et al. (2002). Ac- cording to this protocol, a loop of overnight culture in Luria-Bertani (LB) broth (Fluka, Switzerland) was inoculated into LB broth and incubated at $37^{\circ} \mathrm{C}$ for $18 \mathrm{~h}$ under shaking conditions $(200 \mathrm{rpm})$. This culture $(1.5 \mathrm{~mL})$ was then centrifuged at $14000 \mathrm{rpm}$ for $5 \mathrm{~min}$ and bacterial pellet was resuspended in $20 \mu \mathrm{L}$ of Kado Buffer and $100 \mu \mathrm{L}$ of lysis solution. Following the incubation at $58^{\circ} \mathrm{C}$ for $27 \mathrm{~min}$, $100 \mu \mathrm{L}$ of phenol/chloroform $(1: 1, \mathrm{v} / \mathrm{v})$ was added to that suspension and mixed until its color turns to white. This solution was then centrifuged at $14000 \mathrm{rpm}$ for $30 \mathrm{~min}$. Ninety microliters of supernatant was mixed with $10 \mu \mathrm{L}$ of loading buffer and incubated on ice for $10 \mathrm{~min}$ for electrophoresis of the plasmid DNA; $0.7 \%$ agarose gel was used. Plasmid DNA $(15 \mu \mathrm{L})$ was loaded per well and electrophoresis was performed at $80 \mathrm{~V}$ for $1 \mathrm{~h}$. The gel was then stained in ethidium bromide and visualized under UV light.

Sixteen antibiotics belonging to 7 different groups (Table 1) were used in antibiotic susceptibility testing of the Salmonella strain, which was performed by disc diffusion method according to National Committee for Clinical Laboratory Standard Guidelines (1997) (Bauer et al., 1966). Micro dilution method was also performed to determine the resistance levels of Salmonella strains (CLSI/NCCLS 2005).

The randomly amplified polymorphic DNA-PCR (RAPD-PCR) was performed as previously described by Lin et al. (1996). Two different primers, P1254 (5'-CCG CAG CCA A-3') (Lin et al., 1996) and P1283 (5'-GCG ATC CCC A-3') (Hilton and Penn, 1998) were used in RAPD-PCR analyses. $S$. Typhimurium LT2 was used as the control strain in this analysis. PCR amplification was carried out in a final volume of $50 \mu \mathrm{L}$ containing $5 \mu \mathrm{L}$ of

Table 1 - The antibiotics used in the study.

\begin{tabular}{lc}
\hline Generic name & Group \\
\hline Kanamycin (KAN) & Aminoglycosides \\
Neomycin (NEO) & Aminoglycosides \\
Nalidixic acid (NAL) & Quinolones \\
Tetracycline (TET) & Tetracyclines \\
Spectinomycin (SPE) & Aminoglycosides \\
Sulfonamid (SUL) & Sulfonamides \\
Trimethoprim (TMP) & Folate Antogonist \\
Ampicillin (AMP) & $\beta$-lactam \\
Amoxicillin-Clavulanate (AMC) & $\beta$-lactam \\
Ceftiofur (EFT) & $\beta$-lactam \\
Chloramphenicol (CHL) & Phenicol \\
Florphenicol (FFC) & Phenicol \\
Gentamicin (GEN) & Aminoglycosides \\
Ciprofloxacin (CIP) & Quinolones \\
Trimethoprim-sulfamethoxazole (STX) & Folate antagonist-sulfonamide \\
Streptomycin (STR) & Aminoglycosides \\
\hline
\end{tabular}


10X PCR buffer (100 mM Tris- $\mathrm{HCl} \mathrm{pH:} \mathrm{8.8,} 500 \mathrm{mM} \mathrm{KCl,}$ $0.8 \%$ Nonidet P40), $2 \mu \mathrm{L}$ of dNTP mix $(10 \mathrm{mM}), 1 \mu \mathrm{L}$ of $100 \mu \mathrm{mol} / \mathrm{L}$ primer, $1.25 \mathrm{U}$ of Taq DNA polymerase, $7 \mu \mathrm{L}$ of $\mathrm{MgCl}_{2}(25 \mathrm{mM}), 2 \mu \mathrm{L}$ of template DNA $(100 \mathrm{ng} / \mu \mathrm{L})$ and $30 \mu \mathrm{L}$ of sterilized $\mathrm{H}_{2} \mathrm{O}$. Amplification was performed in GeneAmp9700 thermocycler (Applied BioSystems, USA) with the following conditions: 1 cycle of $94{ }^{\circ} \mathrm{C}$ for $5 \mathrm{~min}$ and 4 cycles of $94{ }^{\circ} \mathrm{C}$ for $4 \mathrm{~min}, 35^{\circ} \mathrm{C}$ for $4 \mathrm{~min}, 72^{\circ} \mathrm{C}$ for $4 \mathrm{~min}$ and followed by 30 cycles of $94^{\circ} \mathrm{C}$ for $30 \mathrm{~min}, 35^{\circ} \mathrm{C}$ for $1 \mathrm{~min}$ and $72{ }^{\circ} \mathrm{C}$ for $5 \mathrm{~min}$. Next, $10 \mu \mathrm{L}$ of each amplified product was mixed with $2 \mu \mathrm{L}$ of $6 \mathrm{X}$ loading dye and were loaded on $2 \%$ agarose gels. The gels were stained with ethidium bromide and visualized under UV light. GeneRuler TM 1kb DNA ladder (Fermentas, Finland) was used as the molecular size marker.

The presence of class I integrons in each Salmonella strain was assessed using 3'-CS and 5'-CS regions specific primers, adjacent to the site specific recombinational insertion sequence (Table 2) (Tosini et al., 1998). The presence of sull, sul2, and sul 3 genes in all sulfonamide resistant isolates was investigated by PCR using primers specific for these genes (Table 2).

\section{Results and Discussion}

In this study, the antibiotic resistance profiles of 4 Salmonella strains, RTE-1, RTE-2, RTE-3, and RTE-4, which were identified from 173 presumptive isolates of 81 RTE salad vegetable samples, were investigated. Although all Salmonella strains were tested for the resistance to 16 antibiotics, resistances to neomycin, sulfonamides, tetracycline, and nalidixic acid were detected predominantly (Table 3). The rapid emergence of antibiotic resistant pathogens is a growing public health concern in all over the world. In recent years, an increase in the occurrence of antimicrobial resistance among various Salmonella serovars has been observed in many countries, including Turkey (Genç and Otlu, 2005; Özbey et al., 2007). However, we had only limited data about the frequency of Salmonella contamination of RTE salad vegetables in Turkey. This is the first report on the identification of Salmonella strains isolated from Turkey-originated RTE salad vegetables. Antibiotic susceptibility testing has been used both to in-

Table 2 - Primer pairs used in determination of sulfonamides resistance genes and integron analysis.

\begin{tabular}{llc}
\hline 3-CS & AAG CAG ACT TGA CCT GA & variable \\
5-CS & GGC ATC CAA GCA GCA AG & variable \\
Sul1-F & CGG CGT GGG CTA CCT GAA CG & 433 \\
Sul1-R & GCC GAT CGC GTG AAG TTC CG & \\
Sul2-F & GCG CTC AAG GCA GAT GGC ATT & 293 \\
Sul2-R & GCG TTT GAT ACC GGC ACC CGT & \\
pVP440sul3F & TCA AAG CAA AAT GAT ATG AGC & 787 \\
P440sul3R & TTT CAA GGC ATC TGA TAA AGA C & \\
\hline
\end{tabular}

Table 3 - Antimicrobial resistance of Salmonella isolates from RTE salads and MIC values of tested antibiotics.

\begin{tabular}{|c|c|c|c|c|}
\hline \multicolumn{5}{|l|}{ Salmonella strains } \\
\hline Tested antibiotics ${ }^{\mathrm{a}}$ & RTE-1 & RTE-2 & RTE-3 & RTE-4 \\
\hline AMP & $\mathrm{S}^{\mathrm{b}}$ & $\mathrm{S}$ & S & S \\
\hline AMC & $\mathrm{S}$ & $\mathrm{S}$ & $\mathrm{S}$ & $\mathrm{S}$ \\
\hline CHL & S & S & S & S \\
\hline CIP & S & $\mathrm{I}(>2)$ & S & $\mathrm{I}(>2)$ \\
\hline EFT & S & $\mathrm{I}(>4)$ & $\mathrm{I}(>4)$ & $\mathrm{I}(>4)$ \\
\hline FFC & S & $\mathrm{I}(>8)$ & S & S \\
\hline GEN & S & S & S & S \\
\hline KAN & S & S & S & S \\
\hline NAL & $\mathrm{S}$ & $\mathrm{S}$ & $\mathrm{S}$ & $\mathrm{R}(>256)$ \\
\hline NEO & $\mathrm{S}$ & $\mathrm{R}(>16)$ & $\mathrm{R}(>16)$ & $\mathrm{R}(>16)$ \\
\hline SPE & S & S & S & S \\
\hline STR & S & $\mathrm{S}$ & $\mathrm{S}$ & $\mathrm{S}$ \\
\hline SUL & $\mathrm{R}(>512)$ & $\mathrm{R}(>128)$ & $\mathrm{R}(>128)$ & $\mathrm{R}(>128)$ \\
\hline TET & $\mathrm{S}$ & $\mathrm{R}(>32)$ & S & $\mathrm{I}(>8)$ \\
\hline TMP & $\mathrm{S}$ & $\mathrm{S}$ & S & S \\
\hline SXT & $\mathrm{S}$ & $\mathrm{S}$ & $\mathrm{S}$ & $\mathrm{S}$ \\
\hline
\end{tabular}

${ }^{\mathrm{a} A M P}$ : Ampicillin; AMC: Amoksicilin/clavulanic asid; CHL: Chloramphenicol; CIP: Ciprofloxacin; EFT: Ceftiofur; FFC: Florphenicol; GEN: Gentamicin; KAN: Kanamycin; NAL: Nalidixic acid; NEO:Neomycin; SPE: Spectinomycin; STR: Streptomycin; SUL: Sulfonamides; TET: Tetracycline; TMP: Trimethoprim.

${ }^{\mathrm{b}} \mathrm{S}$ : sensitive; I: intermediate; R: resistant.

vestigate the increasing numbers of resistant Salmonella causing foodborne diseases and also to type these microorganisms (Oliveira et al., 2007). The antimicrobial resistance observed in the present study is probably due to the widespread use of the commonly available antimicrobials.

Plasmid profile analysis demonstrated that all of the strains carried one to three plasmids with molecular sizes ranging from $5 \mathrm{~kb}$ to $100 \mathrm{~kb}$ (Figure 1). Plasmids are self-replicating extra-chromosomal DNA elements which can contain several genes that encode antimicrobial resistance, toxin production and virulence factors that allow their host to survive in changing conditions, and also some types can conjugally transfer these genes to other strains. By plasmid profile analysis, we can determine a different number of profiles, which depends on geographical location of isolates, time of researching, as well as the origin of strains (Miljkovic-Selimovic et al., 2008). Another research group in Ankara, Turkey examined 64 isolates and identified plasmids which size varied from 2.5 to $100 \mathrm{~kb}$ (Tekeli et al., 2006). The plasmid profiles of our isolates showed similarities with their report. Also several researchers reported that $55 \mathrm{~kb}$ plasmid, the plasmid that we identified in RTE-1, is the most dominating plasmid among Salmonella strains, especially in food-originated isolates (Erdem et al., 1994; Stubbs et al., 1994). 


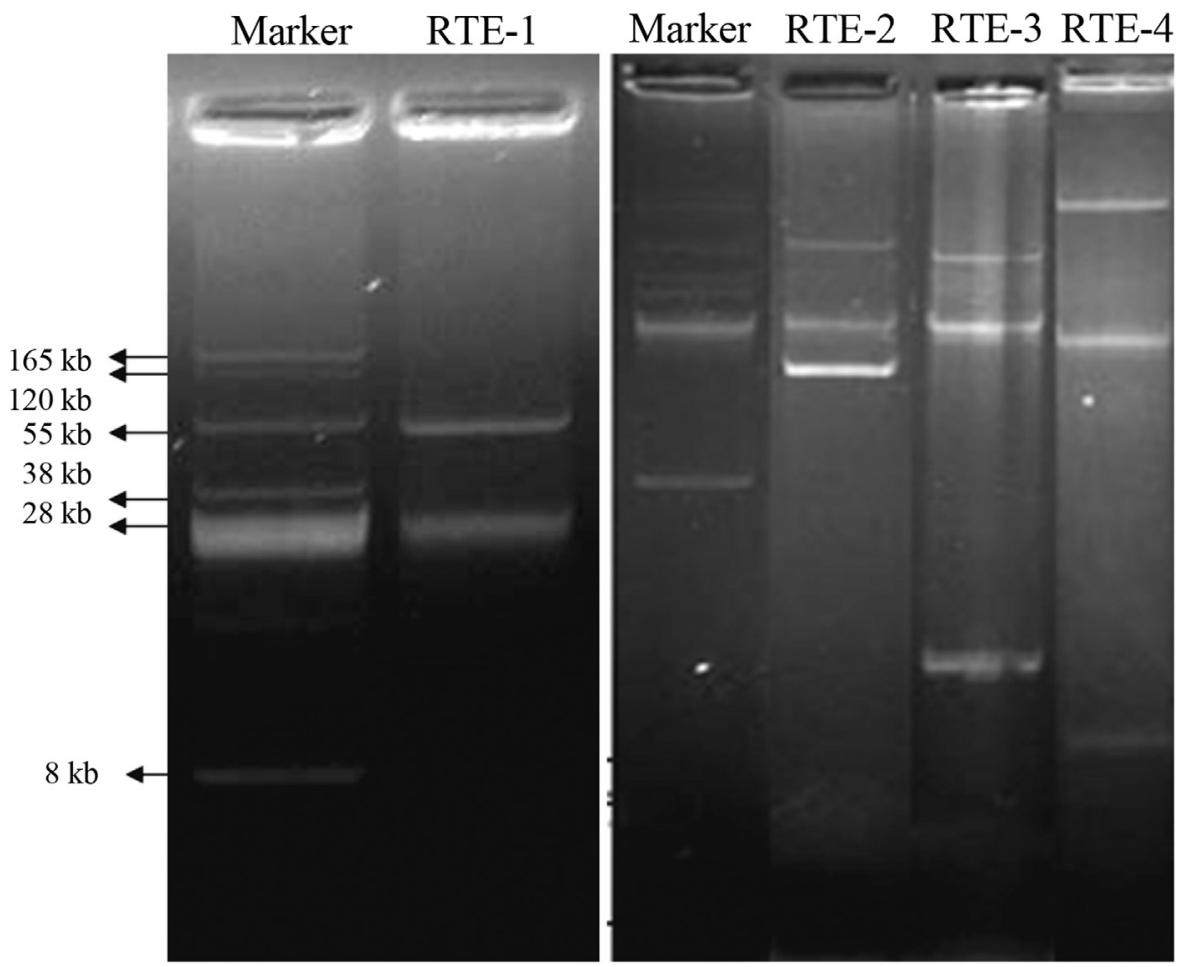

Figure 1 - Plasmid profile of Salmonella strain. Marker: Molecular weight marker (BAC-Tracker Supercoiled DNA Ladder, Epicentre Biotechnologies); RTE-1: $55 \mathrm{~kb}$; RTE-2: $20 \mathrm{~kb}, 66 \mathrm{~kb}$; RTE-3: $5 \mathrm{~kb}, 51 \mathrm{~kb}$; RTE-4: 3 kb, $100 \mathrm{~kb}$.

By RAPD-PCR analysis, it was found that amplified DNA fragments using P1254 and P1283 primers showed molecular weights between $364 \mathrm{bp}$ to $1241 \mathrm{bp}$ and $437 \mathrm{bp}$ to $1966 \mathrm{bp}$, respectively. It was also observed that all strains amplified a common fragment of 354 bp when the P1254 primer was used. Similarly, a $1065 \mathrm{bp}$ fragment was determined as common fragment for all tested strains by the use of P1283 primer. These findings are very important for developing a database Salmonella strains of Turkey origin (Figure 2). Regarding the importance of Salmonella as the cause of a foodborne disease, certain techniques have been used for identification of relations among different isolates and to determine the sources or origins of outbreaks. PCRbased and rapid genotyping methods such as REP-PCR, ERIC-PCR, PCR-ribotyping and RAPD-PCR have been used by different researchers for typing Salmonella (Cerro et al., 2002; Betancor et al., 2004, Smith et al., 2011). Also, it has been reported that RAPD-PCR analysis has greater discriminatory potential than PFGE for the differentiation of Salmonella serovar Enteritidis strains (Betancor et al., 2004). Hilton and Penn (1996) used both primers P1254 and P1283 and reported that these primers provide good discriminatory power among strain of $S$. Enteridis PT4 but were unable to differentiate this strain from other unrelated isolates. Similarly, our experiments of RAPD analysis using P1254 and P1283 could differentiate isolates since each of them produced different different fragments. However, analysis with restriction enzyme combinations and compar- ison of a number of different analytical methods may ensure better identification of isolates. We plan to use restriction enzyme cleavage analysis in our future studies.

The presence of class 1 integrons was determined for all tested Salmonella strains. Three of the isolates contained $1.2 \mathrm{~kb}$ amplicon, except that RTE-3. The amplified fragment of $1 \mathrm{~kb}$ in size was determined as a common amplicon for four of the strains. By the investigation of the relationship of sulfonamide resistance genes with integrons, it was firstly found that Salmonella strains harbored class I integrons with variable regions. A basic role in spread of antimicrobial resistance in Salmonella has been attributed to class 1 integrons (Guerra et al., 2000). These integrons are important in evolution of Salmonella strains due to its different profile from other class I integrons that have been identified in Salmonella strains until now (Figure 3). However, further studies on screening the antibiotic resistance showed that strain RTE-1 had sull and sul2 genes, but not sul3 gene. In addition to these findings, we also determined that sulfonamides resistance (sull and sul2) genes of RTE1 were encoded by the $55.0 \mathrm{~kb}$ plasmid that was not involving any integrons. The sul 3 gene is a new sulfonamide resistance gene that has been previously detected in Salmonella strains (Guerra et al., 2004; Antunes et al., 2005; Kozak et al., 2009). Enne et al. (2001) reported that sulfonamide resistance in Gram-negative bacteria generally arises from the acquisition of either of the genes sul1 and sul2, encoding forms of dihydropteroate synthase that 

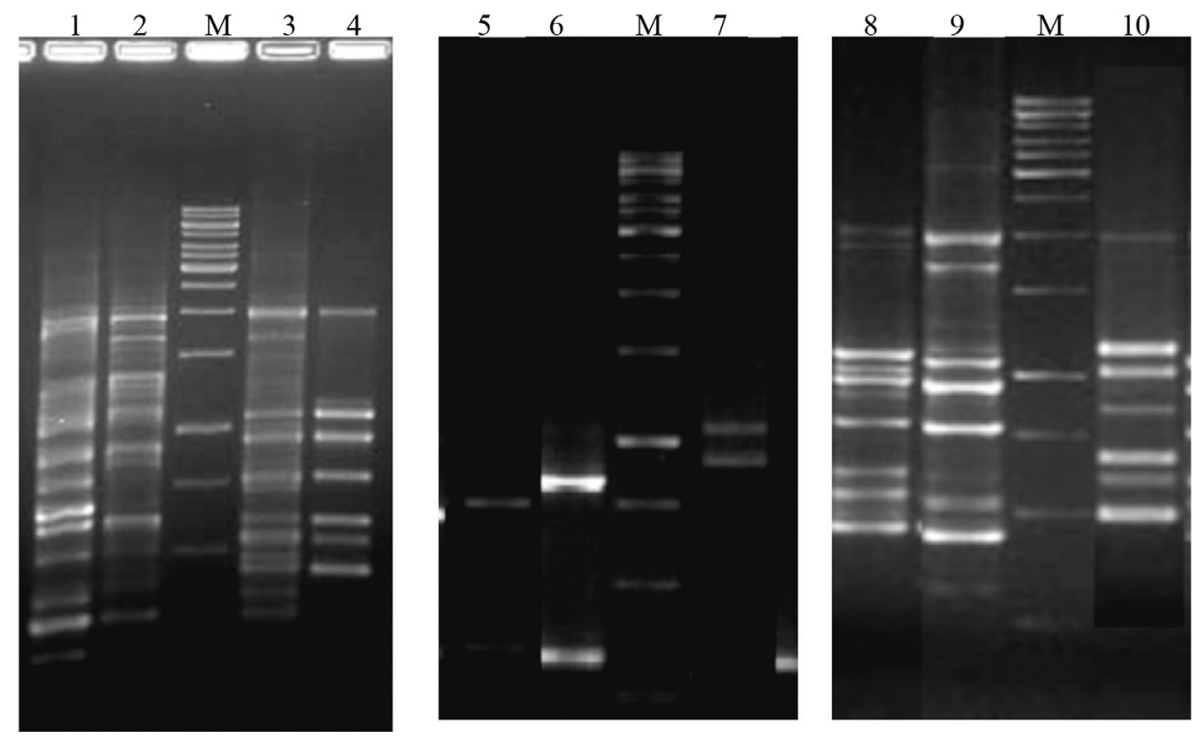

Figure 2 - RAPD-PCR analysis of Salmonella strain. DNA fragment patterns were generated using primers P1254 and P1283. M denotes the molecular weight marker (1 kb Gene Ruler, Fermentas). Lane 1: RAPD profile of $S$. Typhimurium LT2 obtained with primer P1254; Lane 2: RAPD profile of RTE-1 obtained by using P1254 primer; Lane 3: RAPD profile of $S$. Typhimurium LT2 obtained with primer P1283; Lane 4: RAPD profile of RTE-1 obtained by using P1254 primer; Lane 5: RAPD profile of RTE-2 obtained by using P1254 primer; Lane 6: RAPD profile of RTE-3 obtained by using P1254 primer; Lane 7: RAPD profile of RTE-4 obtained by using P1254 primer; Lane 8: RAPD profile of RTE-2 obtained by using P1283 primer; Lane 9: RAPD profile of RTE-3 obtained by using P1283 primer; Lane 10: RAPD profile of RTE-4 obtained by using P1283 primer.

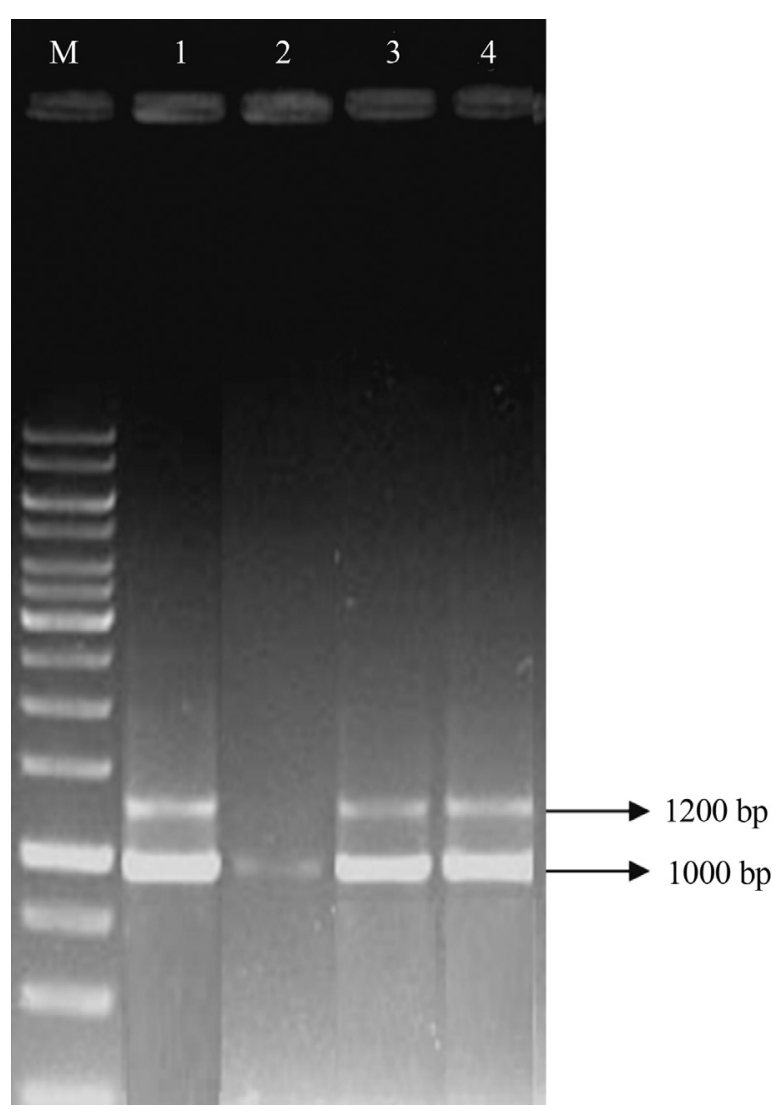

Figure 3 - Analysis of class 1 integrons from Salmonella strains. M denotes the molecular weight marker (1 kb Gene Ruler, Fermentas). Lane 1: Class-1 integrons of RTE-1 (1000 and $1200 \mathrm{bp}$ ), Lane 2: Class-1 integrons of RTE-2 (1000 bp), Lane 3: Class-1 integrons of RTE-3 (1000 and 1200 bp), Lane 4: Class-1 integrons of RTE-4 (1000 and 1200 bp). are not inhibited by the drug. In this study, the highest percentages of resistance were found for sulfonamide (100\%). Similar results were demonstrated by certain researchers (Guerra et al., 2004; Antunes et al., 2005; Kozak et al., 2009). It is of note that serotype Typhimurium was the main serotype carrying the $s u l 3$ gene and the only serotype associated with the three sul genes (Antunes et al., 2005). Serotyping needs to be performed in these RTE salad vegetables that originated Salmonella strains, but following this report and after the comparison of the RAPD-PCR profiles of our RTE strains with control strain $S$. Typhimurium LT2, it could be reported that serotypes of RTE isolates are different from serotype Typhimurium.

\section{Conclusion}

Consumers love the convenience of making salad simply by dumping a pre-washed bag of greens into a bowl. However, for more than a decade, scientists have raised concerns about pathogenic bacteria contamination of these RTE salad vegetables.

Since RTE salad vegetables are exposed to a range of conditions during growth, harvest, preparation and distribution, it is possible that these conditions may increase the potential for pathogenic bacteria contamination and also the contamination with a pathogen that has genetic elements to survive under antimicrobial pressure. This highlights the necessity for the implementation of good hygiene practices from farm to fork to prevent contamination and/or bacterial growth in these salad products. 
Therefore, the findings of this study provide support for the adoption of guidelines for the prudent use of antibiotics for a reduction in the number of pathogens present on food farms, such as vegetables and fruits. Besides, since it is shown that these bacteria started to gain resistance to antibiotics, it is necessary to further investigate the prevalence of them in foods and also to prevent the contamination of freshly consumed foods.

\section{Acknowledgments}

The authors acknowledge financial support from Gazi University Scientific Research Project Unit under a project no. 21/2009-01.

\section{References}

Abadias M, Usall J, Anguera M, Solsona C, Viñas I (2008) Microbiological quality of fresh, minimally-processed fruit and vegetables, and sprouts from retail establishments. Int $\mathbf{J}$ Food Microbiol 123:121-129.

Angulo FJ, Johnson KJ, Tauxe RT, Cohen ML (2000) Origins and consequences of antimicrobial-resistant nontyphoidal Salmonella: implications for the use of fluoroquinolones in food animals. Microb Drug Resist 6:77-83.

Antunes P, Machado J, Sousa JC, Peixe L (2005) Dissemination of sulfonamide resistance genes (sul1, sul2 and sul3) in Portuguese Salmonella enterica strains and relation with integrons. Antimicrob Agents Ch 49:836-839.

Bauer AW, Kirby WMM, Sherris JC, Turck M (1966) Antibiotic susceptibility testing by a standardized single disc method. Am J Clin Pathol 45:493-496.

Betancor L, Schelotto F, Martinez A, Pereira M, Algorta G, Rodríguez MA, Vognoli R, Chabalgoity JA (2004) Random amplified polymorphic DNA and phenotyping analysis of Salmonella enterica serovar Enteritidis isolates collected from humans and poultry in Uruguai from 1995 to 2002. J Clin Microbiol 42:1155-1162.

Beuchat LR (1996) Listeria monocytogenes: Incidence on vegetables. Food Control 7:223-228.

Cerro A, Soto SM, Landeras E, González-Hevia MA, Guijarro JA, Mendoza MC (2002) PCR-based procedures in detection and DNA-fingerprinting of Salmonella from samples of animal origin. Food Microbiol 19:567-575.

Clinical and Laboratory Standards Institute (2005) Performance standards for antimicrobial susceptibility testing. Fifteenth informational supplement. M100-S15 (M2), Table 2A. Wayne, PA.

de Curtis ML, Franceschi O, de Castro N (2002) Listeria monocytogenes in vegetables minimally processed. Arch Latinoam Nutr 52:282-288.

de Giusti M, Aurigemma C, Marinelli L, Tufi D, de Medici D, di Pasquale SI, de Vito C, Boccia A (2010) The evaluation of the microbial safety of fresh ready-to-eat vegetables produced by different technologies in Italy. J Appl Microbiol 109:996-1006.

Enne VI, Livermore DM, Stephens P, Hall LMC (2001) Persistence of sulfonamide resistance in Escherichia coli in the UK despite national prescribing restriction. Lancet 357:1325-1328.
Erdem B, Threlfall EJ, Schofield SL, Ward LR, Rowe B (1994) Plasmid profile typing provides a method for the differentiation of strains of Salmonella enteritidis phage type 4 isolated in Turkey. Lett Appl Microbiol 19:265-267.

European Commission Regulation (2005) No 2073 / 2005 of 15 November 2005 on microbiological criteria for foodstuffs. Official J European Union L 338:1-26.

Fröder H, Martins CG, de Souza KL, Landgraf M, Franco BD, Destro MT (2007) Minimally processed vegetable salads: microbial quality evaluation. J Food Protect 70:77-1280.

Genç O, Otlu S (2005) Salmonella isolations from different avian species in Kars distinct of Turkey. Kafkas Univ Vet Fak 11:25-27 [In Turkish].

Guerra B, Soto S, Cal S, Mendoza MC (2000) Antimicrobial resistance and spread of class I integrons among Salmonella serotypes. Antimicrob Agents Ch 44:2166-2169.

Guerra B, Soto S, Helmuth R, Mendoza MC (2002) Characterisation of a self-transferable plasmid from Salmonella enterica serotype Typhimurium clinical isolates carrying two integron-borne gene cassettes together with virulence and drug resistance genes. Antimicrob Agents Ch 46:2977-2981.

Guerra B, Junker E, Miko A, Helmuth R, Mendoza MC (2004) Characterization and localization of drug resistance determinants in multi-resistant, integron carrying Salmonella enterica serotype Typhimurium strains. Microb Drug Resist-Mech Epidemiol Dis 10:83-91.

Helmuth R, Stephan R, Bunge C, Hoog B, Steinbeck A, Bulling E (1985) Epidemiology of virulence-associated plasmids and outer memrane protein patterns within seven common Salmonella serotypes. Infect Immun 48:175-182.

Hilton AC, Penn CW (1998) Comparison of ribotyping and arbitrarily-primed PCR for molecular typing of Salmonella enterica and relationships between strains on the basis of these molecular markers. J Appl Microbiol 85:933-940.

Kado CI, Liu ST (1981) Rapid procedure for detection and isolation of large and small plasmids. J Bacteriol 145:1365-1373.

Kozak GK, Pearl DL, Parkman J, Reid-Smith RJ, Deckert A, Boerlin P (2009) Distribution of sulfonamide resistance genes in Escherichia coli and Salmonella isolates from swine and chickens at abattoirs in Ontario and Quebec, Canada. Appl Environ Microbiol 75:5999-6001.

Lin AW, Usera AM, Baret TJ, Goldsby RA (1996) Application of random amplified polymorphic DNA analysis to differentiate strains of Salmonella Enteritidis. J Clin Microbiol 34:870-876.

Little CL, Talor FC, Sagoo SK, Gillespie IA, Grant KA, McLauchlin J (2007) Prevalence and level of Listeria monocytogenes and other Listeria species in retail pre-packaged mixed vegetable salads in the UK. Food Microbiol 24:711717.

Little CL, Gillespie IA (2008) Prepared salads and public health. J Appl Microbiol 105:1729-1743.

Long SM, Adak GK, O’Brien SJ, Gillespie IA (2002) General outbreaks of infectious intestinal disease linked with salad vegetables and fruit, England and Wales, 1992-2000. Commun Dis Public Health 5:101-105.

Mercanoglu Taban B, Ben U, Aytac SA (2009) Rapid detection of Salmonella in milk by combined immunomagnetic separation-polymerase chain reaction assay. J Dairy Sci 92:23822388. 
Miljkovic-Selimovic B, Babic T, Kocic B, Stojanovic P, Ristic L, Dinic M (2008) Plasmid profile analysis of Salmonella enterica serotype enteritidis. Acta Medica Medianae 47:54-57.

Miyamoto T, Tian HZ, Okabe T, Trevanich S, Asoh K, Tomoda S, Honjoh K, Shoji H (1998) Application of randomly amplified polymorphic DNA analysis for detection of Salmonella spp. in foods. J Food Protect 61:785-791.

National Committee for Clinical Laboratory Standards (1997) Performance standards for antimicrobial disk susceptibility tests for bacteria that grow aerobically. Approved standard M7-A4. Villanova, PA.

Oliveira FA, Frazzon APG, Brandelli A, Tondo EC (2007) Use of PCR-ribotyping, RAPD, and antimicrobial resistance for typing of Salmonella enteridis involved in foodborne outbreaks in Southern Brazil. J Infect Develop Count 1:170176.

Özbey G, Kök F, Muz A (2007) Isolation of Salmonella spp. in camel sausages from retail markets in Aydyn, Turkey, and polymerase chain reaction (PCR) confirmation. Turk J Vet Anim Sci 31:67-71.

Sagoo SK, Little CL, Ward L, Gillespie IA, Mitchell RT (2003) Microbiological study of ready-to-eat salad vegetables from retail establishments uncovers a national outbreak of salmonellosis. J Food Protect 66:403-409.

Smith SI, Fowora MA, Goodluck HA, Nwaokorie FO, Aboaba OO, Opere B (2011) Molecular typing of Salmonella spp isolated from food handlers and animals in Nigeria. Int J Mol Epidemiol Genet 2:73-77.

Stubbs AD, Hickman-Brenner FW, Cameron DN, Farmer J (1994) Differentiation of Salmonella enteritidis phage type 8 strains: evaluation of three additional phage typing systems, plasmid profiles, antibiotic susceptibility patterns, and biotyping. J Clin Microbiol 32:199-201.

Tekeli A, Erdem B, Sahin F, Koyuncu E, Karasartova D, Bayramova M (2006) Plasmid profiles and randomly amplified polymorphic DNA analysis of Salmonella enterica serotype Enteritidis strains from outbreaks and sporadic cases in Turkey. New Microbiol 29:251-260.

Tosini F, Visca P, Luzzi I, Dionisi AM, Pezzella C, Petrucca A, Carattoli A (1998) Class 1 integronborne multiple-antibiotic resistance carried by IncFI and IncL/M plasmids in Salmonella enterica serotype Typhimurium. Antimicrob Agents Ch 42:3053-3058.

Ward LR, Maguire C, Hampton MD, de Pinna E, Smith HR, Little CL, Gillespie IA, O’Brien SJ, Mitchell RT, Sharp C, Swann RA, Doyle O, Threlfall EJ (2002) Collaborative investigation of an outbreak of Salmonella enterica serotype Newport in England and Wales in 2001 associated with ready-to-eat salad vegetables. Commun Dis Public Health 5:301-304.

Wells JM, Butterfield JE (1997) Salmonella contamination associated with bacterial soft rot of fresh fruits and vegetables in the marketplace. Plant Dis 81:867-872.

All the content of the journal, except where otherwise noted, is licensed under a Creative Commons License CC BY-NC. 